\title{
Guidelines for the management of non-infectious intermediate and posterior uveitis
}

\author{
Marta Misiuk-Hojło', Anna Turno-Kręcicka', Barbara Biziorek², Małgorzata Laskowicz³, Barbara Kozuh4, \\ Joanna Przeździecka-Dołyk', Bogdan Batko ${ }^{5}$ \\ Katedra i Klinika Okulistyki Uniwersytetu Medycznego we Wrocławiu \\ 2 Klinika Chirurgii Siatkówki i Ciała Szklistego Uniwersytetu Medycznego w Lublinie \\ 3 Uniwersyteckie Centrum Kliniczne Okulistyki i Onkologii w Katowicach \\ 4 Samodzielny Publiczny Szpital Kliniczny CMKP w Warszawie \\ 5 Oddział Reumatologii Szpitala Specjalistycznego im. Józefa Dietla w Krakowie
}

\section{Wstęp}

Zapalenia błony naczyniowej (ZBN) stanowią jedną z wiodących przyczyn pogorszenia widzenia. Mogą prowadzić do licznych powikłań ocznych grożących nieodwracalną utratą wzroku.

Istotnym warunkiem prawidłowego rozpoczęcia leczenia ZBN jest zebranie wywiadu z pacjentem i przeprowadzenie właściwej diagnostyki ukierunkowanej na poznanie przyczyny zapalenia. Podstawowym warunkiem podjęcia leczenia objawowego jest wykluczenie infekcyjnej etiologii choroby. We współczesnej okulistyce najwięcej trudności przysparza leczenie nieinfekcyjnych zapaleń błony naczyniowej (NZBN). Obowiązuje indywidualne podejście terapeutyczne zależne od lokalizacji zapalenia, towarzyszących manifestacji ogólnoustrojowych choroby autoimmunologicznej, wspótistnienia innych chorób ogólnoustrojowych, wieku pacjenta, obecnych powikłań okulistycznych zapalenia oraz działań niepożądanych leków. Leczenie NZBN wymaga ścisłej współpracy z lekarzami innych specjalności (np. reumatologami, lekarzami chorób zakaźnych, pulmonologa$\mathrm{mi}$, nefrologami, neurologami, dermatologami). Należy pamiętać, że pierwszą manifestacją choroby ogólnoustrojowej może być ZBN.

\section{Obowiązujące główne linie terapeutyczne leczenia ogól- noustrojowego}

1. Pierwsza linia terapeutyczna - steroidy

a. stosowane do uzyskania szybkiego efektu terapeutycznego w celu wygaszenia stanu zapalnego,

b. rodzaj leku, dawkowanie oraz droga podania zależą od lokalizacji i stopnia nasilenia zapalenia oraz stanu pacjenta,

c. przed ich podaniem należy wykluczyć przeciwwskazania, w tym infekcję ogólnoustrojową, rozregulowaną cukrzycę, aktywną chorobę wrzodową żołądka i dwunastnicy oraz osteoporozę, a także uwzględnić interakcje z innymi lekami,

d. preferowane stosowanie prednizonu lub prednizolonu,

e. leczenie rozpoczynamy od dawki 0,5-1,0 mg/kg masy ciała/dobę w pojedynczej porannej dawce, w przypadku tocznia rumieniowatego i zapalenia współczulnego dawki wynoszą 1-2 mg/kg masy ciała/dobę,

f. z wysokich dawek należy schodzić stopniowo, powoli zmniejszając dawkę,

g. dawka podtrzymująca to około $7,5 \mathrm{mg} /$ dobę, preferowana dawka to około $5,0 \mathrm{mg} /$ dobę,

h. w przypadku ciężkich postaci można rozpocząć leczenie od podawania steroidów dożylnie w dawce $500,0 \mathrm{mg}-$ 1,0 g/dobę przez 3 dni, z następczą kontynuacją leczenia steroidami doustnymi.

2. Druga linia terapeutyczna - konwencjonalne leki immunosupresyjne i immunomodulujące

- Stosowane u pacjentów wymagających leczenia steroidami w dawce wyższej niż 5,0-7,5 mg/dobę w celu ustabilizowania stanu zapalnego.

- Pomagają osiągnąć stabilizację stanu zapalnego przy zastosowaniu małych dawek steroidów.

- Zmniejszają ryzyko nawrotów zapalenia.

- Wybór leku jest indywidualny.

- Przed włączeniem terapii immunosupresyjnej konieczne jest wykonanie podstawowych badań laboratoryjnych, tj. morfologii z rozmazem, określenia stężeń kreatyniny, mocznika, ALAT/ASPAT, GGTP oraz bilirubiny całkowitej, a także badania ogólnego moczu (opcjonalnie).

- Leki immunosupresyjne mają wiele potencjalnych działań niepożądanych (nefrotoksyczność, mielotoksyczność, hepatotoksyczność i zwiększone ryzyko zakażeń). W trakcie terapii należy regularnie kontrolować pacjenta.

- Efekt terapeutyczny zastosowanego leku immunosupresyjnego jest osiągany dopiero po kilku tygodniach.

- 0 braku działania leku immunosupresyjnego można zacząć mówić po 3-6 miesiącach jego stosowania.

- W przypadku braku efektu działania leku immunosupresyjnego należy go zmienić na inny.

- Jeśli dany lek immunosupresyjny wykazuje zbyt słabe działanie przeciwzapalne, można rozważyć dołączenie drugiego leku immunosupresyjnego lub dodanie leku biologicznego albo zamianę tej terapii na terapię biologiczną. 
- W przypadkach wysokiego ryzyka wystąpienia ciężkich powikłań grożących nieodwracalną utratą widzenia należy rozważyć zastosowanie terapii biologicznej w drugiej linii terapeutycznej po wykazaniu niepowodzenia steroidoterapii. W poszczególnych przypadkach może ona stanowić drugą linię leczenia (np. w przypadku choroby Behçeta takie zastosowanie znajdują adalimumab i infliksymab).

Do najczęściej stosowanych leków immunosupresyjnych i immunomodulujących należą:

- metotreksat w dawce 7,5-25,0 mg/tydzień,

- mykofenolan mofetylu w dawce 1,0-2,0 g/dobę,

- cyklosporyna A w dawce 2,0-5,0 mg/kg masy ciała/ dobę,

- takrolimus w dawce 0,05-0,3 mg/kg masy ciała/dobę. Obecnie odchodzi się od stosowania cyklofosfamidu i chlorambucilu w terapii NZBN z uwagi na ryzyko wystąpienia ciężkich działań niepożądanych.

3. Trzecia linia terapeutyczna - leki biologiczne

- Stanowią najnowszą opcję terapeutyczną w leczeniu NZBN.

- Mogą być stosowane razem z konwencjonalną terapią.

- Pozwalają ustabilizować stan zapalny przy zastosowaniu mniejszych dawek steroidów, leków immunosupresyjnych/immunomodulujących.

Należą do nich:

a. monoklonalne przeciwciała przeciwko czynnikowi martwicy nowotworu (ang. anty-tumor necrosis factor - anty-TNF):

- adalimumab (Humira) - jedyny preparat zarejestrowany do leczenia:

$\checkmark$ nieinfekcyjnego zapalenia części pośredniej, tylnej i całej błony naczyniowej u pacjentów dorosłych,

$\checkmark$ zapalenia części przedniej błony naczyniowej towarzyszącego MIZS u dzieci (do 18. roku życia),

- infliksymab,

- golimumab,

- certolizumab pegol;

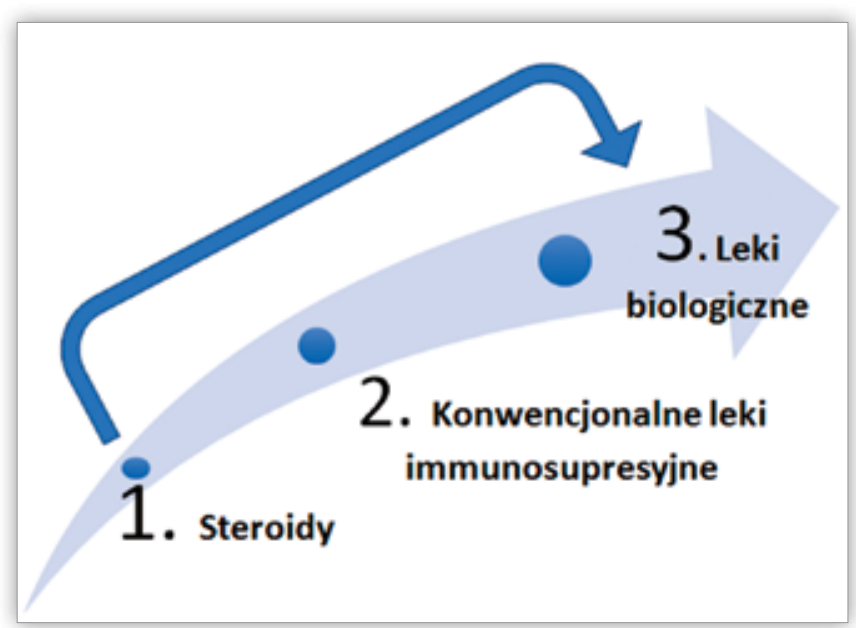

Ryc. 1. Schemat włączania leczenia w aktywnym nieinfekcyjnym zapaleniu błony naczyniowej.

Fig. 1. Schematic stepladder technique of introduction different therapeutic options in uveitis. b. interferony;

c. lek skierowany przeciwko powierzchownym antygenom limfocytów:

- rytuksymab (CD-20);

d. Inne leki antycytokinowe:

- anakinra (IL-1),

- daclizumab (IL-2R),

- tocilizumab (IL-6R),

- sekukinumab (IL-17),

- gevokizumab (IL-1 $\beta$ ),

\section{Zapalenie części pośredniej błony naczyniowej}

W większości przypadków ma ono charakter autoimmunologiczny, nieinfekcyjny, przewlekły, a główne manifestacje kliniczne to wysięk komórkowy w ciele szklistym i obrzęk torbielowaty plamki. Leczenie podejmuje się w sytuacji udokumentowanego obniżenia ostrości wzroku i w razie wystąpienia obrzęku torbielowatego plamki, wskazane są regularna kontrola i indywidualne zalecenia terapeutyczne.

Leczenie pierwszego wyboru:

- steroidy w iniekcjach okołogałkowych preparatów depot: metylprednisolon (DepoMedrol) 40,0 mg nie częściej niż co 1 miesiąc, triamcinolon 40,0 mg (preparaty Volon A, Triamhexal i Kenalog) nie częściej niż co 3 miesiące,

- niesteroidowe leki przeciwzapalne $\mathrm{w}$ kroplach podawane 3 razy dziennie.

Leczenie drugiego wyboru:

- steroidy doustnie np. prednizon lub deflazakort - na początku 1,0 mg/kg masy ciała/dobę, później w dawkach podtrzymujących około 18-12 mg/dobę.

Zapalenie części pośredniej rzadko może towarzyszyć chorobom infekcyjnym: boreliozie, gruźlicy i kile, wtedy leczenie objawowe musi być połączone z leczeniem przyczynowym.

Leczenie powikłań (torbielowatego obrzęku plamki):

- iniekcje okołogałkowe steroidów, iniekcje triamcinolonu do komory ciała szklistego, implanty deksametazonu do komory ciała szklistego,

- niesteroidowe krople przeciwzapalne podawane 3 razy dziennie,

- acetazolamid p.o. we wczesnym stadium,

- w przypadkach opornych na leczenie doszklistkowe podaje się iniekcje leków anty-VEGF,

- trakcje szklistkowo-siatkówkowe, zwłóknienie przedplamkowe - ewentualne leczenie chirurgiczne: witrektomia z peelingiem plamki.

\section{Zapalenie błony naczyniowej w przebiegu nieinfekcyjnych chorób układowych}

\section{Sarkoidoza}

Choroba dotyka zwykle oboje oczu, do najczęstszych manifestacji należą przewlekłe zapalenie tęczówki z zaostrzeniami, zapalenie części pośredniej błony naczyniowej, obrzęk plamki, zapalenie żył siatkówki i ziarniniaki siatkówki. Leczenie jest oparte na steroidoterapii miejscowej, okołogałkowej i ogólnej, w zależności od indywidualnego przebiegu choroby, wieku pacjenta i towarzyszących objawów ogólnoustrojowych. 
Leczenie miejscowe:

- steroidy w kroplach - częstotliwość podawania zależy od stopnia nasilenia objawów, zwykle terapia jest długotrwała,

- mydriatyki-cykloplegiki,

- iniekcje okołogałkowe preparatów steroidów typu depot: Depo-Medrol, tramcinolon 40,0 mg stosuje się w leczeniu części pośredniej błony naczyniowej i torbielowatego obrzęku plamki.

Leczenie ogólne (stosowane szczególnie w ciężkich przewlekłych zapaleniach części pośredniej i tylnej błony naczyniowej, z zapaleniem żył i nawracającym obrzękiem torbielowatym plamki):

- prednizon (Encorton) lub deflazakort (Calcort) początkowo $1,0 \mathrm{mg} / \mathrm{kg}$ masy ciała/dobę, po uzyskaniu efektu terapeutycznego stopniowa redukcja do dawek podtrzymujących 10-20 mg/dobę przez wiele miesięcy i lat. U pacjentów opornych na leczenie konwencjonalne, wymagających przewlekłej terapii steroidami w dawkach powyżej $>10,0 \mathrm{mg}$ na dobę należy rozważyć terapię biologiczną (adalimumab, infliksymab, daclizumab).

Leczenie powikłań:

- jaskry wtórnej,

- obrzęku torbielowatego,

- zakrzepów żylnych siatkówki,

- zaćmy wtórnej.

\section{Choroba Behçeta}

Typowe objawy oczne to obustronne, ostre, nieziarninujące zapalenie tęczówki, wysięk w ciele szklistym, zapalenie żył siatkówki z wtórnymi zakrzepami, torbielowaty obrzęk plamki. Choroba jest przewlekła, prowadzi do licznych powikłań ze względu na swój autoimmunologiczny charakter i poważne rokowanie wymaga długotrwałego leczenia ogólnego.

Leczenie ogólne:

- leki pierwszego wyboru:

$\checkmark$ steroidy: prednizon 1,0 mg/kg masy ciała/dobę, po osiągnięciu efektu terapeutycznego dawki podtrzymujące,

$\checkmark$ leki immunosupresyjne: cyklosporyna $100 \mathrm{mg} /$ dobę w 2 dawkach

lub

- leki drugiego wyboru:

$\checkmark$ azatiopryna $2,0 \mathrm{mg} / \mathrm{kg}$ masy ciała/dobę,

$\checkmark$ interferon alfa $s c$,

$\checkmark$ mykofenolan mofetylu,

$\checkmark$ kolchicyna 0,6 mg 2 razy na dobę doustnie,

$\checkmark$ kombinacje steroidów, cyklosporyny i azatiopryny.

Leczenie wspomagające:

- leki immunomodulujące stosowane w leczeniu choroby Behçeta:

$\checkmark$ adalimumab dawka początkowa $80,0 \mathrm{mg}$ podskórnie, po 7 dniach 40,0 mg, następnie co 2 tygodnie 40,0 mg,

$\checkmark$ infliksymab iv $1,0 \mathrm{mg} / \mathrm{kg}$ masy ciała/ iv co 4 tygodnie.

Leczenie powikłań:

- torbielowatego obrzęku plamki,
- zakrzepów żył siatkówki - laseroterapia obszarów braku perfuzji, panfotokoagulacja w przypadkach neowaskularyzacji,

- krwotoków do komory ciała szklistego, trakcji szklistkowo-siatkówkowych, odwarstwienia siatkówki - witrektomia przez pars plana.

\section{Stwardnienie rozsiane (Sclerosis Multiplex - SM)}

W przebiegu procesów autoimmunologicznych towarzyszących demielinizacji może dochodzić do obustronnego przewlekłego zapalenia tęczówki, zapalenia części pośredniej błony naczyniowej z wysiękiem komórkowym do ciała szklistego i torbielowatym obrzękiem plamki, zapalenia żył siatkówki i zapalenia nerwu wzrokowego (n. II). Manifestacje oczne choroby dobrze reagują na leczenie steroidami, charakteryzują się jednak nawrotami. Nie każdy pacjent chorujący na demielinizacyjne zapalenie pozagałkowe $\mathrm{n}$. II powinien być leczony steroidami. Bolusy dożylne metylprednizolonu (1,0 g iv przez 3 dni) są zarezerwowane jedynie dla wyselekcjonowanych pacjentów z demielinizacyjnym zapaleniem pozagałkowym n. II. Zapalenia błony naczyniowej na tle SM powinny być leczone w zależności od ich umiejscowienia i przebiegu.

Leczenie miejscowe:

- steroidy w kroplach i mydriatyki - cykloplegiki wystarczają w leczeniu przewlekłego zapalenia tęczówki,

- steroidy długo działające - triamcinolon 40,0 mg w iniekcjach okołogałkowych - w leczeniu zapalenia części pośredniej błony naczyniowej, w ciężkich przypadkach triamcinoIon podawany do komory ciała szklistego 20,0 mg (Vitreal), implanty biodegradowalne deksametazonu do komory ciała szklistego (Ozurdex $700 \mu \mathrm{g}$ ).

Leczenie ogólne:

- steroidy - długotrwałe stosowanie dawek podtrzymujących prednizonu,

- leki immunosupresyjne:

$\checkmark$ cyklosporyna $100 \mathrm{mg} /$ dobę w 2 dawkach ${ }^{2}$

$\checkmark$ interferon beta.

Leczenie powikłań:

- torbielowatego obrzęku plamki,

- wtórnej jaskry,

- wtórnej zaćmy,

- trakcyjnego odwarstwienia siatkówki.

\section{Toczeń rumieniowy układowy}

Występujące rzadko okluzyjne zapalenie naczyń siatkówki dotyczy głównie tętniczek, to daje powikłania w postaci neowaskularyzacji z krwotokami do komory ciała szklistego i neuropatii niedokrwiennej $\mathrm{n}$. II.

Leczenie ogólne jest prowadzone przez reumatologa i zależy od towarzyszących manifestacji ze strony innych narządów:

- steroidy ogólnie - w aktywnej postaci choroby, zagrażającej funkcji narządów, zwykle rozpoczyna się od podawania dożylnie metyloprednizolonu (500,0-1000,0 mg przez 3 kolejne dni, następnie kontynuuje się leczenie doustnie - średnie dawki $>7,5 \mathrm{mg}$, lecz $<30,0 \mathrm{mg}$ ekwiwalentu prednizonu/

\footnotetext{
Zgodnie z ChPL 5 mg/kg m.c./dobę w 2 dawkach lub w przypadkach opornych dawkę można zwiększyć do $7 \mathrm{mg} / \mathrm{kg}$ m.c./dobę
}

Zgodnie z ChPL $5 \mathrm{mg} / \mathrm{kg}$ m.c./dobę w 2 dawkach lub w przypadkach opornych dawkę można zwiększyć do $7 \mathrm{mg} / \mathrm{kg} \mathrm{m}$.c./dobę 
dobę), stopniowo redukując dawkę do podtrzymującej $<7,5 \mathrm{mg} /$ dobę),

- leki immunosupresyjne - wybór leku i dawki zależy od stanu ogólnego pacjenta, masy ciała, wydolności nerek i wątroby: $\checkmark$ mykofenolan mofetylu - 2,0-3,0 g/dobę doustnie, i/lub

$\checkmark$ hydroksychlorochina 200,0-400,0 mg/dobę doustnie lub

$\checkmark$ azatiopryna 2,0 mg/ kg masy ciała/dobę lub

$\checkmark$ cyklofosfamid w leczeniu indukującym remisje w dawce $500,0-750,0 \mathrm{mg} / \mathrm{m}^{2}$ masy ciała co 3-4 tygodnie przez 6 miesięcy lub wg schematu Euro-Lupus w stałej dawce dożylnie $500,0 \mathrm{mg} 6$ razy co 2 tygodnie,

$\checkmark$ kwas acetylosalicylowy 100,0-300,0 mg dodatkowo przy obecności przeciwciał antyfosfolipidowych.

Leczenie miejscowe:

- krople steroidowe w zapaleniu twardówki, zapaleniu nadtwardówki i wspótistniejącym zapaleniu tęczówki.

Leczenie powikłań:

- laseroterapia stref braku perfuzji,

- panfotokoagulacja w przypadku neowaskularyzacji siatkówki, rubeozy tęczówki,

- leczenie jaskry wtórnej,

- witrektomia w przypadku krwotoków do komory ciała szklistego.

\section{Ziarniniakowatość $z$ zapaleniem naczyń}

Ta ciężka choroba układowa wywołuje rzadko nekrotyzujące zapalenie naczyń siatkówki, tego konsekwencją jest tworzenie się stref braku perfuzji, wtórnej neowaskularyzacji, krwotoków do komory ciała szklistego, a także jaskry wtórnej.

Leczenie ogólne:

- steroidy na początku choroby, zawsze łącznie z lekami immunosupresyjnymi takimi jak:

$\checkmark$ cyklofosfamid u chorych, u których doszło do zajęcia narządów, 3 cykle leku dożylnie w dawce 15,0 mg/kg masy ciała (maksymalnie 1200,0 mg) co 2 tygodnie, a następne 3 cykle co 3 tygodnie; dawkę leku należy dostosować do wieku pacjenta i stężenia kreatyniny,

$\checkmark$ metotreksat 20,0-25,0 mg/tydzień alternatywnie w in-

lub dukcji remisji i jej podtrzymaniu

$\checkmark$ azatiopryna $2,0 \mathrm{mg} / \mathrm{kg}$ masy ciała/dobę

lub

$\checkmark$ leflunomid $20,0 \mathrm{mg} /$ dobę

Terapia powikłań:

- laseroterapia stref braku perfuzji.

\section{Guzkowe zapalenie tętnic}

Nekrotyzujące zapalenie tętniczek może dotyczyć także siatkówki, powodując ogniska ischemii i martwicy, krwotoczki siatkówkowe, nekrotyzujące zapalenie twardówki i zapalenie tęczówki.

Leczenie ogólne:

- $\quad$ steroidy doustnie - na początku prednizon $1,0 \mathrm{mg} / \mathrm{kg}$ masy ciała/dobę, następnie dawki podtrzymujące w łagodnych postaciach choroby,
- w przypadku ciężkiego przebiegu choroby - leki immunosupresyjne takie jak cyklofosfamid lub azatiopryna.

Terapia powikłań:

- laseroterapia stref braku perfuzji.

\section{Zapalenie skórno-mięśniowe}

W obrębie błony naczyniowej i siatkówki występuje zapalenie tętniczek siatkówki i naczyniówki, z tworzeniem stref ischemii, oraz niedokrwienna neuropatia $\mathrm{n}$. II.

Leczenie ogólne:

- steroidy doustnie - prednizon 1,0 mg/kg masy ciała/dobę, następnie redukcja leku do dawek podtrzymujących, około 10,0 mg/dobę lub w kombinacji z immunosupresją,

- leki immunosupresyjne doustnie lub dożylnie:

$\checkmark$ azatiopryna $2,0 \mathrm{mg} / \mathrm{kg}$ masy ciała/dobę lub

$\checkmark$ metotreksat 20,0-25,0 mg/tydzień z kwasem foliowym w jednorazowej dawce 15,0 mg/tydzień lub mykofenolan mofetylu 2,0-3,0 g/dobę albo cyklofosfamid 2,0 mg/kg masy ciała/dobę.

Leczenie powikłań:

- laseroterapia stref braku perfuzji.

\section{Pierwotne zapalenia naczyń siatkówki}

\section{Zespól oszronionych gałęzi}

Jest to łagodna choroba o nieznanej etiologii, w której dochodzi do jedno- lub obustronnego zapalenia naczyń siatkówki z wytworzeniem pochewek głównie wokół żył, bez cech obliteracji, ostrość wzroku obniża się na skutek lagodnego wysięku do komory ciała szklistego.

Leczenie miejscowe:

- iniekcje okołogałkowe steroidów depot.

\section{Choroba Ealesa}

Choroba o nieznanej etiologii, podejrzewa się to autoimmunologiczne, dochodzi w niej do przewlekłego zapalenia żył siatkówki z wtórną neowaskularyzacją i krwotokami do komory ciała szklistego, mogą się rozwinąć rubeoza tęczówki i jaskra wtórna, a także trakcyjne odwarstwienie siatkówki.

Leczenie:

- panfotokoagulacja laserowa,

- pars plana witrektomia w przypadku masywnego krwotoku do ciała szklistego lub trakcyjnego odwarstwienia siatkówki,

- leczenie jaskry wtórnej.

\section{Rzadkie idiopatyczne zapalenia tylnego odcinka błony naczyniowej: zespoły białych punktów}

\section{Retiochoroidopatia typu birdshot}

W pierwszej fazie choroby obserwuje się obustronnie tagodne zapalenie tęczówki, zapalenie naczyń siatkówki na obwodzie z wysiękiem komórkowym do ciała szklistego, wieloogniskowe płaskie, kremowoźółte ogniska hypopigmentacji na poziomie nabłonka barwnikowego, rozsiane od tarczy $\mathrm{n}$. II do równika. W stadium przewlekłym występują remisje i pogorszenia z rozwojem makulopatii i neuropatii n. II, z uporczywie nawracającym obrzękiem torbielowatym plamki. 
Leczenie ogólne:

- steroidy doustnie, na początku doustnie prednizon $1,0 \mathrm{mg} / \mathrm{kg}$ masy ciała/dobę, następnie redukcja stopniowa z włączeniem cyklosporyny,

- mykofenolan mofetylu,

- cyklosporyna $100 \mathrm{mg} /$ dobę w 2 dawkach ${ }^{3}$ doustnie przez wiele miesięcy i lat z kontrolą stężenia kreatyniny.

Leczenie miejscowe:

- steroidy w kroplach, jeśli występują objawy zapalenia tęczówki,

- steroidy okołogałkowo jako leczenie wspomagające.

Leczenie powikłań:

- leczenie torbielowatego obrzęku plamki,

- leczenie neowaskularyzacji podsiatkówkowej w plamce.

\section{Ostra tylna plackowata epiteliopatia barwnikowa}

Obustronne, wieloogniskowe, kremowe zmiany występują w tylnym biegunie, może im towarzyszyć niewielki wysięk w szklistce.

Leczenie:

- ewentualna iniekcja okołogałkowa steroidu w przypadku znacznego zmniejszenia ostrości wzroku.

\section{Ostre zapalenie nabłonka barwnikowego siatkówki}

Najczęściej jednostronne małe, szare ogniska zapalne w głębokich warstwach siatkówki, głównie w okolicy plamki, nie obserwuje się wysięku w ciele szklistym.

Leczenie nie jest potrzebne, dochodzi do samoistnej poprawy.

\section{Wieloogniskowe zapalenie siatkówki i naczyniówki z zapaleniem całej błony naczyniowej}

W przebiegu tego rzadkiego zespołu charakterystyczne jest obustronne występowanie licznych białoszarych lub żółtych, częściowo ubarwionych, ognisk zapalnych na poziomie nabłonka barwnikowego, z towarzyszącym wysiękiem do komory ciała szklistego i zapaleniem tęczówki, mogą się rozwinąć torbielowaty obrzęk plamki i neowaskularyzacja podsiatkówkowa.

Leczenie ogólne:

- steroidy - prednizon 1,0 mg/kg masy ciała/dobę, po uzyskaniu efektu terapeutycznego stopniowa redukcja dawki,

- w postaciach o przewlekłym przebiegu - cyklosporyna $100 \mathrm{mg} /$ dobę w 2 dawkach ${ }^{4}$

Leczenie miejscowe:

- steroidy w kroplach i iniekcje okołogałkowe steroidów. Leczenie powikłań:

- torbielowatego obrzęku plamki,

- neowaskularyzacji podsiatkówkowej.

\section{Zapalenie naczyniówki ze zwłóknieniem podsiatkówkowym}

W tej bardzo rzadkiej chorobie występują białożółte, zlewające się plamy podsiatkówkowe w tylnym biegunie obojga oczu, obejmujące plamkę i tarczę n. II, z towarzyszącym łagodnym wysiękiem w przedniej komorze i w ciele szklistym. Po 2-4 ty-

\footnotetext{
Zgodnie z ChPL 5 mg/kg m.c./dobę w 2 dawkach lub w przypadkach opornych dawkę można zwiększyć do $7 \mathrm{mg} / \mathrm{kg} \mathrm{m}$.c./dobę

4 Zgodnie z ChPL $5 \mathrm{mg} / \mathrm{kg}$ m.c./dobę w 2 dawkach lub w przypadkach opornych dawkę można zwiększyć do $7 \mathrm{mg} / \mathrm{kg}$ m.c./dobę
}

godniach dochodzi do bliznowacenia i zwłóknienia zmian oraz do rozwoju neowaskularyzacji podsiatkówkowej.

Leczenie ogólne:

- we wczesnych stadiach podejmuje się próby steroidoterapii ogólnej, czasem łączonej z immunosupresją, rzadko udaje się powstrzymać rozwój choroby.

Leczenie powikłań:

- leczenie neowaskularyzacji podsiatkówkowej.

\section{Choroidopatia pełzająca}

Choroba ma charakter przewlekły, nawracający. Obustronnie, często asymetrycznie, występują płaskie szarobiałe ogniska o nieostrych granicach, które rozprzestrzeniają się od tarczy n. II w różnych kierunkach, to powoduje obniżenie ostrości wzroku po zajęciu plamki. Do nawrotów zapalenia dochodzi na brzegach blizn. Czasem rozwija się neowaskularyzacja podsiatkówkowa. Rokowanie i leczenie zależą od umiejscowienia zmian i stopnia ryzyka utraty widzenia centralnego.

Leczenie ogólne:

- steroidy ogólnie 1,0 mg/kg masy ciała/dobę, po osiągnięciu efektu terapeutycznego redukcja dawki steroidów i utrzymanie leczenia immunosupresyjnego,

- cyklosporyna 100,0 mg/ dobę w 2 dawkach,

- w ciężkich przypadkach terapia „potrójna” - steroidy, cyklosporyna i azatiopryna.

Leczenie miejscowe:

- wspomagająco iniekcje okołogałkowe steroidów w postaci depot.

\section{Zapalenie wspótczulne}

Zapalenie współczulne to ciężkie zapalenie autoimmunologiczne, które może być indukowane ciężkim urazem perforującym oka. W oku tzw. „współczulnym” obserwuje się światłowstręt, zapalenie ziarninujące tęczówki z tworzeniem tylnych zrostów i wtórną jaskrą, zapalenie guzkowe tylnego odcinka naczyniówki oraz wysiękowe odwarstwienie siatkówki. Ze względu na ciężki charakter choroby i ryzyko utraty wzroku konieczne jest leczenie przeciwzapalne i immunosupresyjne zwykle przez całe życie.

Leczenie operacyjne:

- enukleacja ślepego oka po urazie może przeciwdziałać rozwojowi zapalenia współczulnego, jeśli jest wykonana do 2 tygodni od doznania urazu, późniejsza enukleacja ślepego oka może zmniejszać intensywność rozwiniętego zapalenia współczulnego.

Leczenie ogólne:

- steroidy - prednizon 1,0-2,0 mg/kg masy ciała/dobę, po wygaszeniu zapalenia utrzymywanie małych dawek na stałe,

- cyklosporyna 100,0 mg/dobę w 2 dawkach jako leczenie uzupełniające w przypadkach opornych na steroidy lub w sytuacjach przeciwwskazań do terapii steroidami,

- leki drugiego wyboru:

$\checkmark$ mykofenolan mofetilu doustnie 2,0 g/dobę

lub

$\checkmark$ metotreksat doustnie 15,0-25,0 mg/tydzień

lub

$\checkmark$ azatiopryna doustnie $50 \mathrm{mg} / 2$ razy na dobę

lub

$\checkmark$ cyklofosfamid 1,0-3,0 mg/kg masy ciała/dobę dożylnie. 
Leczenie miejscowe:

- steroidy w kroplach, iniekcje okołogałkowe steroidów,

- mydriatyki-cykloplegiki,

- leczenie jaskry wtórnej.

\section{Zespót Vogta-Koyanagiego-Harady}

Najczęstsze manifestacje to przewlekłe ziarninujące zapalenie tęczówki i ciała rzęskowego, wieloogniskowe zapalenie tylnego odcinka naczyniówki, wysiękowe odwarstwienie sensorycznej siatkówki oraz obrzęk tarczy n. II.

Leczenie:

Leki pierwszego wyboru:

- steroidy ogólnie - prednizon 1,0 mg/kg masy ciała/dobę ze stopniową redukcją dawki, odpowiedź na steroidoterapię zwykle jest dobra,

- steroidy miejscowo w kroplach, okołogałkowe iniekcje steroidów,

- mydriatyki-cykloplegiki.

Leczenie drugiego wyboru:

- cyklosporyna $100 \mathrm{mg} /$ dobę w 2 dawkach,

- cyklofosfamid 2,0 mg/kg masy ciała/dobę. Leczenie powikłań:

- jaskry wtórnej,

- zaćmy wtórnej,

- neowaskularyzacji podsiatkówkowej.

\section{Piśmiennictwo:}

1. Jabs DA1, Rosenbaum JT, Foster CS, Holland GN, Jaffe GJ, Louie JS, et al.: Guidelines for the use of immunosuppressive drugs in patients with ocular inflammatory disorders: recommendations of an expert panel. Am J Ophthalmol. $2000 \mathrm{0ct}$; 130(4): 492-513.
2. Dick $A D$, Rosenbaum JT, Al-Dhibi HA, Belfort R Jr., Brézin AP, Chee $\mathrm{S}$, et al.: Guidance on Noncorticosteroid Systemic Immunomodulatory Therapy in Noninfectious Uveitis. Fundamentals Of Care for UveitiS (FOCUS) Initiative. The Fundamentals of Care for Uveitis International Consensus Group. Manuscript no. 2017-1794.

3. Kanski's Clinical Ophthalmology. A systemic Approach. Eight Edition. Salmon J, Bowling B, 2015; 396-465.

4. Foster CS, Kothari S, Anesi SD, Vitale AT, Chu D, Metzinger JL, et al.: The Ocular Immunology and Uveitis Foundation preferred practice patterns of uveitis management. Surv Ophthalmol. 2016; 61: 1e17.

5. The Standardization of Uveitis Nomenclature (SUN) Working Group. Am J Ophthalmol. 2005; 140: 509-516.

6. Prost ME, Jachowicz R, Nowak JZ: Kliniczna farmakologia okulistyczna. Elsevier Urban \& Partner, Wrocław 2013, 156-211.

7. Nguyen QD, Merrill PT, Jaffe GJ, Dick AD, Kurup SK, Sheppard $\mathrm{J}$, et al.: Adalimumab for prevention of uveitic flare in patients with inactive non-infectious uveitis controlled by corticosteroids (VISUAL II): a multicentre, double-masked, randomised, placebo- controlled phase 3 trial. Lancet. 2016; 388: $1183 e 1192$.

8. Levy-Clarke G, Jabs DA, Read RW, Rosenbaum JT, Vitale A, Van Gelder RN: Expert panel recommendations for the use of anti-tumor necrosis factor biologic agents in patients with ocular inflammatory disorders. Ophthalmology. 2014; 121: 785e796.e783.

9. Wakefield D, McCluskey P, Wildner G, Thurau S, Carr G, Chee SP, et al.: Inflammatory eye disease: pre-treatment assessment of patients prior to commencing immunosuppressive and biologic therapy: recommendations from an expert committee. Autoimmun Rev. 2017; 16: 213e222. 